\title{
Effects of Atropa belladonna as an Anti-Cholinergic
}

Hemangi Rajput*

Essence Natural Health Clinic, Canada

\begin{abstract}
Atropa belladonna, commonly known as 'deadly nightshade' or 'Belladonna' is known to be extremely toxic. The toxicity is caused by the alkaloids atropine, scopolamine and hyoscyamine which are produced in the plant. The alkaloids present in Atropa belladonna have toxic anti-cholinergic effects on the body. The anti-cholinergic toxidrome affects both central and peripheral nervous system, causing acute delirium, hallucination, tachycardia, dry mouth, flushed skin, vomiting and blurry vision. Both medicinal and toxic anti-cholinergic effects produced by Atropa belladonna alkaloids atropine, scopolamine and hyoscyamine on central and peripheral nervous system are discussed in this study.
\end{abstract}

Keywords: Atropa belladonna; Atropine; Scopolamine; Anticholinergic; Muscarinic antagonists

\section{Introduction}

The plant Atropa belladonna is a perennial herb belonging to the family Solanaceae [1]. It is known to be extremely toxic and the name Atropa is derived from "Atropos" in Greek mythology that refers to one of the three fates which cut the fate of life; and Belladonna meaning "beautiful women" in Italian [2]. In ancient Roman times, the extract of this plant was used by women to dilate pupils to make them look attractive and also applied to the cheeks to give a pinkish-red glow to the skin [3]. Traditionally in Europe, during the middle ages, the plant was used as an herb to treat various illnesses, and also used as poison due to its toxicity [4]. The plant grows in the wild and is native to Europe, Africa, and Asia. It grows about 4 to 5 feet tall and has thick oval dark green foliage with black cherry-like berries making it look identical to blueberries and attractive to eat. This also happens to be a common reason for intoxication after ingestion of these berries in adults and children's [1]. The intoxication is caused by the alkaloids atropine, scopolamine and hyoscyamine, which are present in the berries, leaves and roots. The intoxication causes anti-cholinergic effects on the body causing anti-cholinergic toxidrome [1]. The anticholinergic effects produced by the Atropa belladonna alkaloids cause delirium, hallucination, tachycardia, mydriasis (dilated pupils), dry mouth, flushed skin, blurred vision, urinary retention, vomiting and anhidrosis $[5,6]$.

\section{Effect of Atropa belladonna on the central nervous system}

The Atropa belladonna alkaloids atropine and scopolamine are known to be antagonist for muscarinic receptors. They block the muscarinic receptor acetylcholine, which plays an important role in the functioning of the brain for learning, memory and orientation. In the event of the muscarinic blockade, the absence of acetylcholine causes dysfunctional memory, disorientation and hallucination [2]. The respiratory rate increases and in some cases of overdose, leads to respiratory and cardiovascular failure $[7,8]$.

\section{Effect of Atropa belladonna on peripheral nervous system}

The alkaloid atropine acts as muscarinic antagonist and blocks the parasympathetic postganglionic muscarinic receptors [1,2,6]. Atropine has a stronger effect than scopolamine in producing tachycardia and cardiovascular changes, although the peripheral effects of both atropine and scopolamine are the same $[9,10]$. The signs of peripheral effects manifested by the parasympathetic block include decreased secretions causing dryness of mouth, flushed skin, mydriasis, vomiting, constipation, urinary retention, fever, tachycardia and hypertension [1,2].

\section{Atropa belladonna intoxication}

The severity of the symptoms caused by Atropa belladonna poisoning may vary from mild to moderate to severe, depending on the dose and source. The concentration of the alkaloids present in the berries and leaves may also differ depending on the species. Some species of Atropa belladonna are hybrid and may not produce all the symptoms of toxic anti- cholinergic syndrome [1]. Repetition should also be kept in mind when determining the severity of the symptoms, as central effects are dose and source dependant $[1,2,11]$. Atropine crosses the blood brain barrier and patients with central anticholinergic syndrome show loss of memory, confusion, disorientation, hallucination, in-coordinated movements and agitated delirium with acute psychosis $[1,2]$. Severe cases of central anti-cholinergic toxidrome may present with coma, seizures, respiratory and cardiovascular failure [2]. The peripheral toxicity produced by the alkaloids of Atropa belladonna causes inhibition of secretions and relaxation of smooth muscles in the gastro-intestinal and urinary tract, leading to dryness of mouth, constipation, diminished bowel sounds or ileus and urinary retention [11]. The heart rate increases (tachycardia) with hypertension as a result of parasympathetic block caused by anti-cholinergic agents. Ocular changes include pupillary dilation with paralysis of the ciliary muscle which results in loss of accommodation [5,11].

\section{Medicinal use of Atropa belladonna}

In Europe, through ancient times, plants from deadly nightshades were used to treat various airway diseases e.g. the fumes from the burnt plants were inhaled for relief from bronchoconstriction [4]. Muscarinic antagonists are known to be used as bronchodilators in asthma treatments. Due to their side effects, the anti-cholinergic drugs are not the first line of treatment; instead $\beta$-adrenergic receptor agonists and anti-inflammatory corticosteroids are routinely administered in patients with asthma and chronic obstructive pulmonary diseases $[4,12]$. In the late 1800s, Atropa belladonna was therapeutically used to treat Parkinson's diseases because of its naturally occurring alkaloids, atropine and scopolamine [13]. Atropine is also effective in treating

*Corresponding author: Hemangi Rajput, Essence Natural Health Clinic, Canada, E-mail: essenceclinic@yahoo.com

Received January 18, 2013; Accepted January 28, 2013; Published January 30 2013

Citation: Rajput H (2013) Effects of Atropa belladonna as an Anti-Cholinergic Nat Prod Chem Res 1:104. doi:10.4172/2329-6836.1000104

Copyright: (c) 2013 Rajput $\mathrm{H}$. This is an open-access article distributed under the terms of the Creative Commons Attribution License, which permits unrestricted use, distribution, and reproduction in any medium, provided the original author and source are credited. 
certain cardiovascular conditions like bradycardia, though low doses of atropine have shown to cause bradycardia [7]. Atropine is also used as a premedication in anesthesia, along-with other anticholinergics, since it decreases secretions [9]. Atropa belladonna alkaloids act as anti-emetics, anti-spasmodic and are also effective in the treatment of gastro-intestinal ulcers [14].

\section{Conclusion}

Atropa belladonna has been used for centuries in the treatment of various illnesses, both in conventional and traditional medicine. Although there are many side effects and contradictions of Belladonna, the valuable medicinal qualities far exceed the dangers of unwanted sideeffects and accidental intoxication. Only if we could better understand and research the posology of the clinically potential alkaloids of Atropa belladonna, than it could be used as an effective drug in the treatment of various respiratory, cardiovascular, neuromuscular and gastrointestinal conditions, without the fear of toxicity.

\section{References}

1. Berdai MA, Labib S, Chetouani K, Harandou M (2012) Atropa belladonna intoxication: a case report. Pan Afr Med J 11: 72

2. Joshi P, Wicks AC, Munshi SK (2003) Recurrent autumnal psychosis. Postgrad Med J 79: 239-240.

3. Cikla U, Turkmen S, Karaca Y, Ayaz AF, Turedi S, et al. (2011) An Atropa belladonna L. poisoning with acute subdural hematoma. Hum Exp Toxicol 30: 1998-2001.

4. Moulton BC, Fryer AD (2011) Muscarinic receptor antagonists, from folklore to pharmacology; finding drugs that actually work in asthma and COPD. $\mathrm{Br}$ Pharmacol 163: 44-52.

5. Caksen H, Odabaş D, Akbayram S, Cesur Y, Arslan S, et al. (2003) Deadly nightshade (Atropa belladonna) intoxication: an analysis of 49 children. Hum Exp Toxicol 22: 665-668.

6. Laffargue F, Oudot C, Constanty A, Bedu A, Ketterer-Martinon S (2011) Deadly nightshade (Atropa belladonna) intoxication in a 2-year-old child. Arch Pediatr 18:186-188.

7. Mirakhur RK, Dundee JW (1980) Comparison of the effects of atropine and glycopyrrolate on various end-organs. J R Soc Med 73: 727-730.

8. Bouziri A, Hamdi A, Borgi A, Hadj SB, Fitouri Z, et al (2011) Datura stramonium L. poisoning in a geophagous child: a case report. Int J Emerg Med 4:31

9. Mirakhur RK, Dundee JW (1979) Cardiovascular changes during induction of anaesthesia. Influence of three anticholinergic premedicants. Ann R Coll Surg Engl 61: 463-469.

10. Diaz DM, Diaz SF, Marx GF (1980) Cardiovascular effects of glycopyrrolate and belladonna derivatives in obstetric patients. Bull N Y Acad Med 56: 245-248.

11. Fidan T, Kirpinar I (2011) Psychiatric Aspects of a Case with Deadly Nightshade Intoxication. Journal of academic emergency medicine 10: 86-88.

12. National Heart Lung and Blood Institute, National Asthma Education and Prevention Program (2007) EPR-3 Expert Panel Report 3 (EPR3): Guidelines for the Diagnosis and Management of Asthma (EPR-3). Department of Health and Human Services, National Institutes of Health, US Department of Health \& Human Services, USA.

13. Adler CH (2008) Amantadine and anti-cholinergics. Parkinson's DiseaseDiagnostic and Clinical Management Demos, New York.

14. Mintzer J, Burns A (2000) Anticholinergic side-effects of drugs in elderly people. J R Soc Med 93: 457-462. 